\title{
The Current State of Physical Activity and Exercise Programs in German-Speaking, Swiss Psychiatric Hospitals: Results from a Brief Online Survey [Corrigendum]
}

Brand S, Colledge F, Beeler N, et al. Neuropsychiatr Dis Treat. 2016;12:1309-1317.

Page 1309, Abstract, Methods, the text "All psychiatric hospitals $(\mathrm{N}=55)$ in the German-speaking part of Switzerland were contacted in spring 2014" should read "All psychiatric hospitals $(\mathrm{N}=55)$ in the German-speaking part of Switzerland were contacted in spring 2012".

The authors apologize for this error and advise it does not affect the results of the paper.

\section{Publish your work in this journal}

Neuropsychiatric Disease and Treatment is an international, peerreviewed journal of clinical therapeutics and pharmacology focusing on concise rapid reporting of clinical or pre-clinical studies on a range of neuropsychiatric and neurological disorders. This journal is indexed on PubMed Central, the 'PsycINFO' database and CAS, and is the official journal of The International Neuropsychiatric Association (INA). The manuscript management system is completely online and includes a very quick and fair peer-review system, which is all easy to use. Visit http://www.dovepress.com/testimonials.php to read real quotes from published authors. 